\title{
EMPLOYMENT AS AN INDICATOR OF IMMIGRANTS INTEGRATION IN A HOST SOCIETY
}

\author{
Magdaléna Př́ivarová
}

\author{
University of Economics in Bratislava, Slovakia
}

Integration of immigrants into the labor market is an important issue for all host countries. Active participation in the labor market is essential if population of a host country is going to accept the growing number of immigrants. The statistical data shows that in the European Union there are differences in labor market indicators between nationals and foreigners. Such a situation may result in the phenomenon of immigrants being "overqualified", which is the case in the most of the EU countries. Integration policies in the labor market (including the establishment of language training programs and more efficient procedures for assessment and recognition of qualifications acquired abroad) can help with guaranteeing the equality of opportunities for all. In the case of Slovakia specifically, the study shows that the immigrants are in an unfavorable position in the local labor market as compared to nationals and citizens of other EU countries, especially Western ones.

Keywords: labor migration; integration of immigrants; EU; Slovakia

\section{Introduction}

In contemporary societies, work is a central activity that contributes to the establishment of social bonds among the society members. Work-related activities facilitate socialization because employees of the same company are forming collective links between each other.

The issue of individuals' integration into the labor market is even more important in the case of immigrants specifically for several reasons. Employment is the main source of income for most immigrants. The research shows that one of the main drivers for immigration is the level of economic development in a country of origin (Př́vara, 2019). Besides, given that immigration can be a way to fill labor shortages - in the context of aging population - immigrants must be well integrated into the society of a host country.

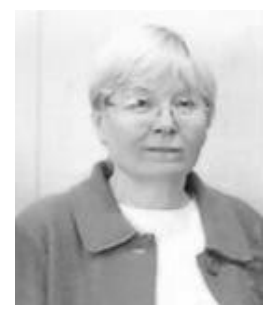

\section{Magdaléna Přívarová}

PhD, Professor at the Department of Economics, University of Economics in Bratislava, Bratislava, Slovak Republic

Research interests: international migration, EU labor market, international regulation of labor migration.

E-mail: magdalena.privarova@euba.sk 
In this context, we can consider low employment rate among immigrants in a host country as the main obstacle to integration.

However, integrating immigrants into the labor market is important not only from the economic point of view. It also encourages their integration into society as a whole, for example, by facilitating access to housing, contacts with the local population, etc.

In most of the EU countries, however, immigrants have poorer employment outcomes than local people (see below). Immigrants are also the first to be laid off in the times of a crisis (Perspectives des migrations internationals, 2019).

\section{The importance of employment rate for immigrants' integration}

We can say that the employment rate is a quite viable indicator which highlights the difficulties in integrating immigrants into the labor market. According to the Eurostat study for 2014-2017, the number of migrants in Europe increased by 18 million (Le taux de chômage des jeunes en Europe, 2018).

Table 1 - The number of migrants in Europe, 2014-2017

(Source: http://appsso.eurostat.ec.europa.eu/nui/show.do?dataset=migr_imm8\&lang=en)

\begin{tabular}{|c|c|c|c|c|}
\hline GEO/TIME & 14 & 2015 & 2016 & 2017 \\
\hline United King & 631991 & 631452 & 588993 & 644209 \\
\hline Italy & 277631 & 280078 & 300823 & 343440 \\
\hline Spain & 305454 & 342114 & 414746 & 532132 \\
\hline Germany (u & 884893 & 1543848 & 1029852 & 917109 \\
\hline France & 340383 & 364221 & 378115 & 369964 \\
\hline Poland & 222275 & 218147 & 208302 & 209353 \\
\hline Switzerland & 156282 & 153627 & 149305 & 143377 \\
\hline Romania & 136035 & 132795 & 137455 & 177435 \\
\hline Netherlands & 145323 & 166872 & 189232 & 189646 \\
\hline Sweden & 126966 & 134240 & 163005 & 144489 \\
\hline Czechia & 29897 & 29602 & 64083 & 51847 \\
\hline Austria & 116262 & 166323 & 129509 & 111801 \\
\hline Greece & 59013 & 64446 & 116867 & 112247 \\
\hline Norway & 66903 & 60816 & 61460 & 53351 \\
\hline Denmark & 68388 & 78492 & 74383 & 68579 \\
\hline Ireland & 73519 & 80792 & 85185 & 78499 \\
\hline Portugal & 19516 & 29896 & 29925 & 36639 \\
\hline Slovenia & 13846 & 15420 & 16623 & 18808 \\
\hline Hungary & 54581 & 58344 & 53618 & 68070 \\
\hline Finland & 31507 & 28746 & 34905 & 31797 \\
\hline Cyprus & 9212 & 15183 & 17391 & 21306 \\
\hline Luxembourg & 22332 & 23803 & 22888 & 24379 \\
\hline
\end{tabular}

Concerning employment, improvement in the employment rate of the recently arrived immigrants is more the case in the countries where it was already relatively high, such as Ireland and the United Kingdom. On the other hand, no improvement is observed in the 


\section{EMPLOYMENT AS AN INDICATOR OF IMMIGRANTS}

countries where the situation on the labor market was less favorable at the start, such as Italy and France, where only around $40 \%$ of recent immigrants were employed as of 2018. This information comes from the study published by OECD (2019).

Table 2. Employment rate by citizenship, as of 2018

(Source: Finding your marks 2019)

\begin{tabular}{|c|c|c|c|}
\hline \multirow[t]{2}{*}{ Country } & \multicolumn{3}{|c|}{ The employment rate, in \%, 15-64 y.o. } \\
\hline & Nationals & $\begin{array}{l}\text { Nationals of another } \\
\text { EU Member State }\end{array}$ & $\begin{array}{l}\text { Nationals of a non- } \\
\text { EU country }\end{array}$ \\
\hline Germany & 76 & 77 & 60 \\
\hline Austria & 74 & 73 & 58 \\
\hline Belgium & 64 & 64 & 46 \\
\hline Bulgaria & 63 & $:$ & 58 \\
\hline Cyprus & 62 & 66 & 66 \\
\hline Croatia & 56 & 63 & 55 \\
\hline Denmark & 76 & 75 & 59 \\
\hline Spain & 61 & 61 & 54 \\
\hline Estonia & 74 & 69 & 70 \\
\hline Finland & 70 & 70 & 53 \\
\hline France & 66 & 66 & 52 \\
\hline Greece & 54 & 55 & 53 \\
\hline Hungary & 68 & 73 & 70 \\
\hline Ireland & 64 & 68 & 57 \\
\hline Italy & 58 & 61 & 58 \\
\hline Latvia & 70 & 69 & 64 \\
\hline Lithuania & 70 & 62 & 69 \\
\hline Luxembourg & 63 & 72 & 59 \\
\hline Malta & 65 & 71 & NA \\
\hline Netherlands & 78 & 75 & 57 \\
\hline Poland & 66 & 65 & 58 \\
\hline Portugal & 67 & 72 & 68 \\
\hline Slovak Republic & 66 & 58 & 67 \\
\hline Czech republic & 73 & 72 & 74 \\
\hline Romania & 62 & NA & NA \\
\hline United Kingdom & 76 & 78 & 67 \\
\hline Slovenia & 70 & 60 & 62 \\
\hline Sweden & 80 & 76 & 60 \\
\hline EU total & 68 & 71 & 59 \\
\hline
\end{tabular}

We can see that in all the EU countries, except Cyprus, Croatia, and Hungary, the employment rate among immigrants is lower than that of natives. What are the causes for such a situation? Here we should emphasize on the socio-demographic characteristics of immigrants, such as gender, level of education and age. 
It can be seen that in most of the EU countries the employment rate of immigrant women is lower than the employment rate of indigenous women. There are many reasons for this. We will mention two that are particularly relevant.

First, many immigrant women were motivated to come abroad to join their husbands (so the main reason for moving to another country was initially not related to work).

Second, in their countries of origin, the employment rate of women, as a rule, is generally very low.

Among the socio-demographic characteristics, the important role plays the age of immigrants. Currently, an especially acute issue in the EU countries is the unemployment of young people (aged 15-24). As of April 2019, $3.21 \mathrm{mln}$ young people under the age of 25 were unemployed in the countries of the European Union.

In the three EU countries, the unemployment rate of young immigrants exceeds $30 \%$. These are Spain, Greece, and Italy.

Another important characteristic is the achievements in education. Immigrants are generally overrepresented among people with less than upper secondary education (see Tab. $3)$.

In many countries, a significant part of this population has not reached the first cycle of secondary education, generally considered as the minimum level to be operational at the labor market. However, on the other hand, the research shows that some countries, e.g. Finnland, implement programs to attract talents to do their studies in their internationally recognized education systems, providing them also with well-functioning public services, social welfare, healthcare, etc. (Přívara et al., 2020).

\section{The main determinants of immigrant integration in the labor market}

We can divide the determinants of immigrants' integration within the labor market into individual determinants (e.g., socio-demographic characteristics of immigrants) and institutional determinants (e.g., labor market integration policies).

Among the EU countries, there are huge differences in national immigration policies. We should mention that some of these policies have negative effects on the integration process. For example, in Austria and in Slovakia certain measures create insecurity for the status of residents in the event of unemployment.

Being unemployed for a long time lead to the non-renewal of the residence permit, that is to say, to forced return to a country of origin. This measure puts great pressure on immigrants. If he/she loses the job, he/she has to find a new job very quickly and very often this sort of pressure forces immigrants to accept whatever job is offered, even if it is poorly paid and does not correspond to a person's education, competences and/or expectations.

However, some other European countries carry out immigration policies facilitating integration. As an example of good practice, we can mention the programs enabling immigrants to integrate effectively (for example, language training programs).

This is the case, for example, in Sweden where immigrant workers have the right to learn Swedish during their working hours.

In most other countries, including Italy and Spain, language training and systems aimed at encouraging social integration of immigrants and their participation in the neighborhood life. The related activities are organized by local authorities or by non-governmental organizations, sometimes financed by the state. 


\section{EMPLOYMENT AS AN INDICATOR OF IMMIGRANTS}

Table 3 - Levels of education for the populations born abroad and born in the country, aged 15 to 64 , data as of $2009-2010$

(Source: Finding your marks 2018)

\begin{tabular}{|l|c|c|c|c|c|c|}
\hline \multirow{2}{*}{} & \multicolumn{3}{|c|}{ People born abroad } & \multicolumn{3}{c|}{ People born in the country } \\
\cline { 2 - 7 } & $\begin{array}{c}\text { Very weak } \\
\text { ISCED 0-1 }\end{array}$ & $\begin{array}{c}\text { Low } \\
\text { ISCED 0-2 }\end{array}$ & $\begin{array}{c}\text { Student } \\
\text { ISCED 5-8 }\end{array}$ & $\begin{array}{c}\text { Very weak } \\
\text { ISCED 0-1 }\end{array}$ & $\begin{array}{c}\text { Low } \\
\text { CITE0-2 }\end{array}$ & $\begin{array}{c}\text { Student } \\
\text { ISCED 5-8 }\end{array}$ \\
\hline Germany & 13 & 35 & 23 & 2 & 10 & 28 \\
\hline Austria & 3 & 28 & 29 & 0 & 13 & 31 \\
\hline Belgium & 20 & 38 & 30 & 7 & 23 & 37 \\
\hline Bulgaria & 2 & 8 & 47 & 4 & 20 & 26 \\
\hline Cyprus & 9 & 25 & 34 & 12 & 20 & 40 \\
\hline Croatia & 4 & 24 & 18 & 2 & 17 & 21 \\
\hline Denmark & 6 & 26 & 40 & 3 & 27 & 31 \\
\hline Spain & 19 & 44 & 24 & 9 & 43 & 34 \\
\hline Estonia & 0 & 10 & 40 & 1 & 18 & 34 \\
\hline Finland & 4 & 24 & 32 & 4 & 14 & 39 \\
\hline France & 21 & 39 & 29 & 6 & 19 & 35 \\
\hline Greece & 19 & 39 & 17 & 15 & 26 & 31 \\
\hline Hungary & 2 & 15 & 29 & 1 & 17 & 23 \\
\hline Ireland & 4 & 12 & 50 & 9 & 24 & 38 \\
\hline Italy & 9 & 49 & 13 & 6 & 38 & 18 \\
\hline Latvia & 0 & 6 & 33 & 1 & 11 & 33 \\
\hline Lithuania & 1 & 3 & 37 & 2 & 6 & 39 \\
\hline Luxembourg & 12 & 29 & 45 & 4 & 24 & 28 \\
\hline Malta & 1 & 46 & 27 & 8 & 56 & 18 \\
\hline Netherlands & 15 & 30 & 28 & 6 & 22 & 36 \\
\hline Poland & 1 & 4 & 53 & 1 & 8 & 28 \\
\hline Portugal & 15 & 32 & 31 & 34 & 54 & 22 \\
\hline Slovakia & 0 & 10 & 28 & 1 & 10 & 22 \\
\hline Czech Rep & 0 & 13 & 31 & 0 & 7 & 22 \\
\hline Romania & $:$ & $:$ & $:$ & 5 & 26 & 16 \\
\hline UK & 3 & 17 & 49 & 1 & 21 & 39 \\
\hline Slovenia & 2 & 23 & 18 & 1 & 12 & 32 \\
\hline Sweden & 10 & 30 & 41 & 1 & 12 & 32 \\
\hline EU-28 total & 12 & 34 & 29 & 5 & 22 & 29 \\
\hline
\end{tabular}

It can be said that the strategies for integrating immigrants into the labor market involve a wide range of measures. These measures include, among other things, a better match between the skills of immigrants and the jobs offered to them through more efficient procedures for the assessment and recognition of qualifications acquired abroad and the implementation of active labor market policies.

In the context of procedures for the recognition of diplomas acquired abroad, it should be recalled that many EU countries have already adopted measures encouraging the immigration of highly qualified workers (via the EU Blue Card). 
However, according to statistical data, in all the countries with a large immigrant population, immigrants with a high level of education have lower employment rates than their native counterparts. Moreover, around $35 \%$ of people in the EU with tertiary education are employed in low and medium-skilled professions - around 50\% (as of 2018) in the case of those from Central and Eastern Europe. This phenomenon clearly shows significant losses for the mobile workers themselves and also for the countries of both destination and origin.

This suggests that immigrants may find it difficult to apply their credentials in the labor market of a host country. In other words, qualifications and professional experience obtained abroad are significantly undervalued on the labor market of a host country of migrants.

This can be partly explained by the fact that employers sometimes feel that the qualifications acquired in foreign countries are not fully "equivalent" to those obtained in the national context.

Besides, mastery of a host country language is considered to be an important factor if the job requires a high level of qualification. For these reasons, immigrants in most of the EU countries are affected by the phenomenon of "overqualification". In this context, it should be remembered that currently, many local workers are also in a situation of "overqualification". This information is very important to avoid overly optimistic expectations on the part of highly qualified immigrants.

Active labor market measures are generally considered to be an essential tool for the integration of immigrants into the labor market. However, their general scope has recently been limited. Some EU countries, such as Spain, Greece, and Portugal, have reduced the share of their budget allocated to active labor market measures as well as to other measures aimed at promoting the integration of immigrants into this market.

\section{The current situation with labor immigrants in Slovakia}

Currently, Slovakia has about $5.5 \mathrm{mln}$ inhabitants. The number of foreigners staying in the country is 121,264 people. Of them, 55,902 are originally from the EU countries and 64,362 are from third countries (Migration in Slovakia: IOM, 2018).

During the last economic and financial crisis there were no significant changes in the development of migration. Slovakia has seen a slow but systematic and steady increase in the number of immigrants since this country has joined the EU. But because of the small proportion of immigrants in relation to the total population number, the economic impact of migration is still considered to be marginal (Ministry of interiors of Slovak Republic, 2018).

In 2018, foreigners from around 130 countries were employed in our country, mainly from Serbia $(13,561)$, Ukraine $(11,842$, with the one-time annual increase of 7,216), Romania (11,072), the Czech Republic (6,062) and Hungary (5933).

\section{Integration of immigrants into Slovak labor market}

The access of foreign workers to Slovak labor market is closely linked to their status and their stay in the country. The degree of stability of the authorization granted influences the migrant's desire to integrate into Slovak society.

The entry and stay of the EU and EEA nationals are regulated by a regime that puts them on equal footing with Slovak citizens. That is why it is more relevant to focus on the regime for third-country nationals. 


\section{EMPLOYMENT AS AN INDICATOR OF IMMIGRANTS}

In Slovakia, there are three types of stays:

- permanent stay

- temporary stay

- tolerated stay.

Permanent and temporary stays are the most essential as they are providing immigrants with the possibility of entering the labor market. The tolerated stay regime is special. It can be up to 180 days and does not guarantee the right to request a work permit. This possibility is mainly attributed to family reunification.

A foreigner from a third country who plans to settle in Slovakia to work, study or for doing business, can acquire, under certain conditions mentioned in the law, the authorization for a temporary stay.

After this type of stay has been granted, the immigrant may remain in the territory of Slovak Republic for the period of two years maximum. The authorization is granted for a certain purpose which must be documented together with the request. The renewal of authorization can be made for the maximum period of three years.

The permanent residence permit is a more stable type of stay. Foreigners with this type of stay have the same rights and the same obligations as nationals - employment, social assistance, medical assistance, etc. The first authorization is granted for the maximum period of five years, however, a renewal can be requested for an unlimited period. During the first such a request, the individual concerned must also document their financial situation, health insurance in Slovakia as well as accommodation.

As already mentioned above, the EU and EEA citizens have the same legal status as Slovak citizens. However, when entering Slovak labor market, the EU citizens must undergo the registration process.

On the other hand, in the case other countries' nationals there are several regimes depending on the legal status of an applicant. A foreigner must usually go through the authorization process by which he/she is granted work authorization and consequently also gets temporary residence authorization for job execution. Foreigners who have already received a permanent residence permit are not required to apply for such a work permit. Moreover, they enter the labor market in the same way as Slovak citizens.

In analyzing the current situation with immigrants at Slovak labor market, it is also necessary to mention certain weaknesses which can be considered as obstacles for foreigners.

First and foremost, this would be the case when an immigrant wishes to leave work and find another one.

In the event of end or change of employment, the employer is obliged to inform the Labor Office that the immigrant's employment has ended, this needs to be done within seven days. The latter must inform the police the reason for which the authorization has been withdrawn.

The end of employment then results in the suspension of immigrant's authorization to stay. He/she is then obliged to leave the country in 30 days, return to their country of origin, and to apply for a new authorization for a temporary stay.

Finally, in the event of dismissal, the immigrant's work permit is automatically canceled. The unemployed migrant must leave Slovakia and apply for a new foreign residence permit. 


\section{Conclusion}

Statistical data shows that there are considerable differences in the area of immigrant labor market integration policies. Each European state must take into account its specific conditions.

Concerning Slovakia, we can see the unfavorable position of immigrants as compared to other EU countries, especially Western ones. This situation is caused by the two main factors: very strict regulation over the admission and employment of immigrants and also the fact that under Slovak legislative system immigrants are perceived as a threat more than a vulnerable group that requires additional protection.

\section{Acknowledgment}

This research was funded by Vega research project no. 1/0037/20: "New challenges and solutions for employment growth in changing socio-economic conditions" and VEGA research project no. 1/0287/19 "Integration of immigrants in EU countries from the point of view of migration policies".

\section{References:}

Le taux de chômage des jeunes en Europe (2018). Available at: https://www.touteleurope.eu/actualite/le-taux-de-chomage-des-jeunes-en-europe.html

Migration in Slovakia: IOM. (2018). Available at: https://www.iom.sk/ sk/migracia/migracia-naslovensku.html

Ministry of interiors of Slovak Republic (2018). Pobyt cudzinca. Available at: https://www.minv.sk/?pobyt-cudzinca

OECD Economic Surveys: Slovak Republik. (2019). Paris: OECD

Perspectives des migrations internationales (2019). Paris: OECD.

Př́vara, A. (2019) Explaining Emigration Patterns In Estonia, Lithuania, Slovenia And Slovakia. Geographical Journal, 71 (2), 161-180.

Př́ivara, A., Rievajová, E. \& Barbulescu, A. (2020) Attracting High Skilled Individuals in the EU: The Finnish Experience. Migration letters, 17(2), 369 - 377.

Trouver ses marques: Les indicateurs de l'OCDE sur l'intégration des immigrés (2019). Available at: www.oe.cd/indicateurs-integration-immigres.

Paper submitted

Paper accepted for publishing

Paper published online
O2 July 2020

11 September 2020

30 September 2020 